\title{
Editorial
}

\section{The Paradox of the Chicken and the Egg: Lack of Actionable Diagnostics Prevents Global Burden of Disease Assessment and Deployment of Public Health Preventive Measures}

\author{
Vinetz JM ${ }^{1 *}$ \\ ${ }^{1}$ Division of Infectious Diseases, Department of Medicine, University of California, San Diego La Jolla, California, USA
}

Keywords: Leptospirosis; Global burden; Public health preventive measures

Copyright: () 2015 Vinetz JM.This is an open access article distributed under the Creative Commons Attribution License, which permits unrestricted use, distribution, and reproduction in any medium, provided the original work is properly cited.

\author{
*Correspondence: jvinetz@ucsd.edu \\ Cite this article as Vinetz JM. The Paradox of the Chicken and the Egg: Lack of Actionable Diagnostics Prevents \\ Global Burden of Disease Assessment and Deployment of Public Health Preventive Measures. Anuradhapura Medical \\ Journal 2015;9(1):1-4. \\ DOI: http://dx.doi.org/10.4038/amj.v9i1.7538
}

Leptospirosis, a bacterial zoonosis, is a globally important emerging infectious disease. The magnitude of its public health importance in most regions and countries remains unknown, both in terms of clinical diagnosis and overall burden of disease, which supports the designation of leptospirosis as a neglected tropical disease. Indeed, the Director of the World Health Organization formally appointed an advisory council, the Leptospirosis Epidemiology Reference Group (LERG), to assess the global burden of leptospirosis.

(www.who.int/zoonoses/diseases/lerg/en/index.html).

The work of LERG has been preliminarily reported (1). An essential finding from the LERG reports is that systematic data to assess the global burden of disease are lacking. The lack of clinically responsive diagnostic tests combined with insufficient systematic study of affected human populations remains a major impediment to understanding the impact of leptospirosis on affected human populations at the clinical, public health and policy levels. This difficulty in diagnosis leads to a paucity of data so that leptospirosis is usually not recognized as a public health threat. Hence, public health approaches to prevent and ameliorate this disease through environmental remediation of hot spots of transmission or novel vaccine or other preventive interventions do not receive programmatic priority by governmental and private research funding organizations or by public health agencies. This story is typical of neglected tropical diseases. However, in the case of leptospirosis, which has the capability of causing explosive epidemics (and predictably and regularly does so around the world) of acute febrile illness, jaundice, renal failure, pulmonary hemorrhage, refractory shock and death, the stakes are too high not to develop new ways to identify, treat, and prevent this disease.

The overall strategy of any global research effort to develop new, globally applicable leptospirosis diagnostic tools has to based on organizing epidemiology and clinical research groups in a diversity of leptospirosis-endemic setting. The current state of diagnostic testing for leptospirosis is poor and relies primarily on decades-old testing methods that are inexact, slow, and not useful at the point of care, hence leading to delayed or missed opportunities for timely clinical care and public health interventions. In the developing world, reference laboratories are generally based at government-supported entities; in the industrialized world, reference laboratories are far removed from the field setting where the burden of disease is highest. Leptospirosis has sporadic, $(2,3,4)$ highly endemic $(5,6,7,8)$ and explosively epidemic patterns of disease, $(9,10,11)$ which are related to how humans interact with the environment around them and the diversity of Leptospiradue to the presence of mammalian reservoir hosts such as rodents, dogs and livestock. Sporadic leptospirosis occurs dramatically in the context of intermittent activities in which people come into contact with Leptospira-contaminated environmental surface waters and wet soils, for example during the EcoChallenge Sabah in 2000(12) or other adventure traveler events such as triathlons.(13)

Progress in addressing the global threat of leptospirosis rests on the premise that the development of new clinically timely diagnostics for acute leptospirosis is an essential tool for controlling this disease. Major efforts need to be 
deployed at the level of laboratory-based discovery to develop rapid, robust and reliable diagnostic tests that are accurate in different globally representative epidemiological settings and that reflect the high diversity of infectious members of the genus Leptospira, which is an important potential barrier to diagnosis. $(2,14,15) \mathrm{Key}$ to diagnostics development is studying diverse and representative patient populations to produce a wellcharacterized specimen bank.(16)The diversity of infecting Leptospira will make it essential to prioritize diagnostic reagents to those that detect the most clinical significant infecting species/serovars. The recent genome-level protein microarray work pioneered and led by the Felgner and Ko groups $(17,18)$ will need to focus not only Leptospirainterrogans serovar Copenhageni (the globally most important infecting strain but not the only cause of severe leptospirosis), but also take into account the existing and forthcoming comprehensive genomic information which indicates some cross-reactive protein antigens among pathogenic Leptospira, but also significant differences in ortholog and paralog content at the genomic level (http://gcid.jcvi.org/projects/gsc/leptospira/).Current commercially-available serological assays use soluble sonicated antigens from the saprophytic (non-infectious) Leptospira biflexa as antigen;(19) assays based on this antigen have relatively poor sensitivity (ranging from 20$60 \%$ on the acute serum sample) and have neither prognostic nor epidemiological implications in terms of progression to severe disease nor zoonotic source of infection, respectively.

The gold standard diagnosis of leptospirosis has traditionally been the microscopic agglutination test (MAT) that primarily detects antibodies to leptospiral surface lipopolysaccharide. Using the MAT as the gold standard has recently been called into question(20) because molecular tests (conventional and quantitative real time PCR) detect more cases than does MAT.( 20, 21) Isolation of Leptospira from clinical samples requires specialized medium, $(22,23)$ equipment and handling, and is poorly sensitive, time-intensive, inefficient and difficult, even though essential for understanding many aspects of Leptospirabiology. Molecular testing, while clearly the newest gold standard, is relatively expense and, hitherto, has required fairly sophisticated facilities, expertise and training, not typically easily available and clinically actionable in leptospirosis-affected settings.

A new generation of leptospirosis diagnostic testing is urgently needed. The leptospirosis field considers this disease to be woefully neglected with significant burden of disease related not only morbidity but to mortality. New diagnostic tests need specifically to identify acute leptospirosis, predict the need for antibiotic treatment (all Leptospiraare susceptible to most $(24,25,26,27,28)$, and indicate the need for hospitalization. New tests must be able to quantify endemicity, identify infection hotspots, identify infecting Leptospiraspecies/serovars and strains, towards the goal of interrupting transmission at the public health level. Such tests need to provide the essential data to be actionable in clinical practice and to underlie key data for enabling public health policy makers to make decisions for intervention. The chicken and the egg paradox is this: funding is needed for diagnostics development in leptospirosis, but without having the data to justify such funding-whether from governmental or philanthropic sources - such diagnostics development will be difficult to pursue.

\section{References}

1. Abela-Ridder B, Sikkema R, Hartskeerl RA.Estimating the burden of human leptospirosis. International Journal of Antimicrobial Agents 2010; 36(Suppl 1): S5-7. DOI: http://dx.doi.org/10.1016/j.ijantimicag.2010.06.012

2. Russell KL, Montiel Gonzalez MA, Watts DM, Lagos-Figueroa RC, Chauca G, Ore M, Gonzalez JE, Moron C, Tesh RB, Vinetz JM. An outbreak of leptospirosis among Peruvian military recruits. The American Journal of Tropical Medicine and Hygiene 2003;69: 53-7.

3. Salkade HP, Divate S, Deshpande JR, Kawishwar V, Chaturvedi R, Kandalkar BM, Vaideeswar P. A study of autopsy findings in 62 cases of leptospirosis in a metropolitan city in India. Journal of Postgraduate Medicine 2005;51: 169-73.

4. Vinetz JM, Glass GE, Flexner CE, Mueller P, Kaslow DC. Sporadic urban leptospirosis. Annals of Internal Medicine 1996;125: 794-8.

DOI: http://dx.doi.org/10.7326/0003-4819-125-10-199611150-00002

5. Ganoza CA, Matthias MA, Saito M, Cespedes M, Gotuzzo E, Vinetz JM. Asymptomatic renal colonization of humans in the peruvian Amazon by Leptospira. PLOS Neglected Tropical Diseases 2010; 4: e612. DOI: http://dx.doi.org/10.1371/journal.pntd.0000612

6. Agampodi S, Peacock SJ, Thevanesam V. The potential emergence of leptospirosis in Sri Lanka.The Lancet Infectious Diseases 2009;9: 524-6. DOI: http://dx.doi.org/10.1016/S1473-3099(09)70211-7 
7. Agampodi SB.Spatial epidemiology of leptospirosis in Sri Lanka. Epidemiology and Infection 2012;140: 1530-1. DOI: http://dx.doi.org/10.1017/S0950268811002512

8. Agampodi SB, Dahanayaka NJ, Bandaranayaka AK, Perera M, Priyankara S, Weerawansa P, Matthias MA, Vinetz JM. Regional differences of leptospirosis in Sri Lanka: observations from a flood-associated outbreak in 2011. PLOS Neglected Tropical 2014; 8: e2626.

DOI: http://dx.doi.org/10.1371/journal.pntd.0002626

9. Ko AI, Galvao RM, Dourado CMR, Johnson WD, Riley LW. Urban epidemic of severe leptospirosis in Brazil. Lancet 1999;354: 820-825. DOI: http://dx.doi.org/10.1016/S0140-6736(99)80012-9

10. Yanagihara Y, Villanueva SY, Yoshida S, Okamoto Y, Masuzawa T. Current status of leptospirosis in Japan and Philippines. Comp Immunol Microbiol Infect Dis 30: 399-413.

11. Mendoza MT, Roxas EA, Ginete JK, Alejandria MM, Roman AD, Leyritana KT, Penamora MA, Pineda CC. Clinical profile of patients diagnosed with leptospirosis after a typhoon: a multicenter study. The Southeast Asian journal of tropical medicine and public health 2013;44:1021-35.

12. Centers for Disease Control and Prevention (CDC). Update: outbreak of acute febrile illness among athletes participating in Eco-Challenge-Sabah 2000--Borneo, Malaysia, 2000. MMWR Morbidity and mortality weekly report $2001 ; \mathbf{5 0}(2): 21-4$.

13. Morgan J, Bornstein SL, Karpati AM, Bruce M, Bolin CA, Austin CC, Woods CW, Lingappa J, Langkop C, Davis B, Graham DR, Proctor M, Ashford DA, Bajani M, Bragg SL, Shutt K, Perkins BA, Tappero JW. Outbreak of leptospirosis among triathlon participants and community residents in Springfield, Illinois, 1998. Clinical Infectious Diseases 2002;34: 1593-9. DOI: http://dx.doi.org/10.1086/340615

14. Bharti AR, Nally JE, Ricaldi JN, Matthias MA, Diaz MM, Lovett MA, Levett PN, Gilman RH, Willig MR, Gotuzzo E, Vinetz JM. Leptospirosis: A zoonotic disease of global importance.The Lancet Infectious Diseases 2003;3: 757-771.

DOI: http://dx.doi.org/10.1016/S1473-3099(03)00830-2

15. Levett PN.Leptospirosis. Clinical Microbiology Reviews 2001;14: 296-326. DOI: http://dx.doi.org/10.1128/CMR.14.2.296-326.2001

16. Bajani MD, Ashford DA, Bragg SL, Woods CW, Aye T, Spiegel RA, Plikaytis BD, Perkins BA, Phelan M, Levett PN, Weyant RS. Evaluation of four commercially available rapid serologic tests for diagnosis of leptospirosis. Journal of Clinical Microbiology 2003;41: 803-9. DOI: http://dx.doi.org/10.1128/JCM.41.2.803-809.2003

17. Lessa-Aquino C, Borges Rodrigues C, Pablo J, Sasaki R, Jasinskas A, Liang L, Wunder EA, Jr., Ribeiro GS, Vigil A, Galler R, Molina D, Liang X, Reis MG, Ko AI, Medeiros MA, Felgner PL. Identification of seroreactive proteins of Leptospira interrogans serovar copenhageni using a high-density protein microarray approach. PLOS Neglected Tropical Diseases 2013;7: e2499. DOI: http://dx.doi.org/10.1371/journal.pntd.0002499

18. Lessa-Aquino C, Wunder EA, Jr., Lindow JC, Rodrigues CB, Pablo J, Nakajima R, Jasinskas A, Liang L, Reis MG, Ko AI, Medeiros MA, Felgner PL. Proteomic Features Predict Seroreactivity against Leptospiral Antigens in Leptospirosis Patients.Journal of Proteome Research 2015;14: 549-56. DOI: http://dx.doi.org/10.1021/pr500718t

19. Smits HL, Ananyina YV, Chereshsky A, Dancel L, Lai AFRF, Chee HD, Levett PN, Masuzawa T, Yanagihara Y, Muthusethupathi MA, Sanders EJ, Sasaki DM, Domen H, Yersin C, Aye T, Bragg SL, Gussenhoven GC, Goris MG, Terpstra WJ, Hartskeerl RA.International multicenter evaluation of the clinical utility of a dipstick assay for detection of Leptospira-specific immunoglobulin M antibodies in human serum specimens. Journal of Clinical Microbiology 1999;37: 2904-9.

20. Limmathurotsakul D, Turner EL, Wuthiekanun V, Thaipadungpanit J, Suputtamongkol Y, Chierakul W, Smythe LD, Day NP, Cooper B, Peacock SJ. Fool's gold: Why imperfect reference tests are undermining the evaluation of novel diagnostics: a reevaluation of 5 diagnostic tests for leptospirosis. Clin Infect Dis 2012;55: 322-31. DOI: http://dx.doi.org/10.1093/cid/cis403 
21. Agampodi SB, Matthias MA, Moreno AC, Vinetz JM. Utility of quantitative polymerase chain reaction in leptospirosis diagnosis: association of level of leptospiremia and clinical manifestations in Sri Lanka. Clinical Infectious Diseases 2012;54: 1249-55.

DOI: http://dx.doi.org/10.1093/cid/cis035.

22. Palmer M, Waitkins SA, Zochowski W. Survival of leptospires in commercial blood culture systems. Zentralblatt für Bakteriologie, Mikrobiologie, und Hygiene. Series A, Medical microbiology, infectious diseases, virology, parasitology 1984; 257(4):480-7.

23. Palmer MF, Zochowski WJ. Survival of leptospires in commercial blood culture systems revisited. Journal of Clinical Pathology 2000;53: 713-4.

DOI: http://dx.doi.org/10.1136/jcp.53.9.713

24. Galloway RL, Levett PN, Tumeh JW, Flowers CR. Assessing cost effectiveness of empirical and prophylactic therapy for managing leptospirosis outbreaks. Epidemiology \& Infection 2009;137: 1323-32. DOI: http://dx.doi.org/10.1017/S0950268808001751

25. Suputtamongkol Y, Niwattayakul K, Suttinont C, Losuwanaluk K, Limpaiboon R, Chierakul W, Wuthiekanun V, Triengrim S, Chenchittikul M, White NJ. An open, randomized, controlled trial of penicillin, doxycycline, and cefotaxime for patients with severe leptospirosis. Clinical Infectious Diseases 2004 39: 1417-24.

DOI: http://dx.doi.org/10.1086/425001

26. Moon JE, Rivard RG, Griffith ME, Ressner RA, McCall S, Reitstetter RE, Hospenthal DR, Murray CK. Effect of timing and duration of azithromycin therapy of leptospirosis in a hamster model. Journal of Antimicrobial Chemotherapy 2007;59: 148-51.

DOI: http://dx.doi.org/10.1093/jac/dkl453

27. Griffith ME, Hospenthal DR, Murray CK. Antimicrobial therapy of leptospirosis. Current Opinion in Infectious Diseases 2006;19: 533-7.

28. Murray CK, Hospenthal DR.Determination of susceptibilities of 26 Leptospira sp. serovars to 24 antimicrobial agents by a broth microdilution technique. Antimicrobial Agents and Chemotherapy 2004; 48: 4002-5. DOI: http://dx.doi.org/10.1128/AAC.48.10.4002-4005.2004

\section{Submit your next Manuscript to Anuradhapura Medical Journal}

Submit your manuscript at

http://amj.sljol.info/ 